\title{
EFFECT OF BLEND RATION ON QUALITY CHARACTERISTICS OF BAMBOO/COTTON BLENDED RING SPUN YARN
}

\author{
C Prakash ${ }^{1}$, G Ramakrishnan ${ }^{2}$ and C V Koushik ${ }^{1}$ \\ ${ }^{1}$ Sona College of Technology, Department of Fashion Technology, Salem 636005, Tamilnadu, India \\ and ${ }^{2}$ TIFAC-CORE, Kumaraguru College of Technology, Coimbatore 641006, Tamilnadu, India \\ Email: dearcpraksah@rediffmail.com
}

\begin{abstract}
The present study reveals the comparison of physical properties of the bamboo/cotton blended yarn with similar $100 \%$ cotton yarn. The bamboocotton blend ratios of each category of yarn $\left(30^{\mathrm{s}}, 40^{\mathrm{s}}\right.$ and 50 ) were 67:33, 50:50, and 33:67, respectively. For each individual count of yarn, it was observed from the test result that the properties of 50:50/bamboo: cotton blended yarn showed very nearer property to the $100 \%$ cotton yarn. For Count $\left(30^{s}\right)$, 67:33/bamboo: cotton showed very closer property to the 50:50/bamboo: cotton blended yarn. It was also observed that for each count of yarns, which showed decreasing property with the increase of bamboo in the blend. The quality characters depend upon the ratio of bamboo and cotton in the blend
\end{abstract}

Keywords: Blending, Yarns, Bamboo/Cotton ratio, Ring spun yarn, Physical Properties

\section{Introduction}

Textile fibres are of course blended for desirable combinations of properties ${ }^{1,} 2$, and intimate blending, which is an almost random mixing of different staple fibres, is the most common practice.

Natural fibres and their blends with classic fibres bear valuable properties, so at present there are various products made of these fibres. It determine that absorbing and discharging moisture, nonirritating, antibacterial, antiallergic, protection against the sun's harmful Ultra Violetic rays and other valuable properties are better, than classic yarns. They may be used for clothing, underwear, socks, hygienic, textile products as well as for composites ${ }^{3}$.

Blending in the cotton spinning process has the objective to produce yarn with acceptable quality and reasonable cost. A good quality blend requires the use of adequate machines, objective techniques to select bales and knowledge of its characteristics. Knowing its importance in the textile industry and its rising cost, the achievement of an economic and good quality blend of different kinds of cotton becomes more and more critical ${ }^{4}$.

Blending of fibres is usually made with different fibres having dissimilarity in their properties, with a view to achieving or improving certain characters of the yarn or its processing performances. Fabric produced from the blended yarn might have better characteristics than what could be obtained in a fabric produced from a single fibre. The blending of cotton is done to develop drape properties, comfortability, durability, dyeability and many other properties of the fabric products. Any successful attempt to blended this fibre with cotton would be a breakthrough in the field of textile. The most important property of a textile fibre is the spinning property.

Blending different types of fibres is a widely practiced means of enhancing the performance and the aesthetic qualities of a fabric. Blended yarns from natural and man-made fibres have the particular advantage of successfully combining the good properties of both fibre components, such as comfort of wear with easy care properties. These advantages also permit an increased variety of products to be made, and yield a stronger marketing advantage ${ }^{6}$. Prediction of the mechanical properties of blended yarns

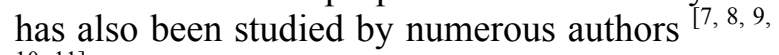
10,11]. Theoretical and mathematical models have been proposed in these studies.

The Bamboo and bamboo-cotton blended yarns are a key part of the 'natural product' theme and being endorsed for use in 'soft look/soft feel' 
textiles, like Towels, knits and socks and also in home-textiles being sourced by leading global MNC Brands. Yarns of bamboo fiber provide the desirable properties of high absorbency, anti microbial and soft feel in textiles and made ups. The present study was conducted in order to find out the impact of bamboo/cotton ratio on the quality characteristics of yarn and also to find out the optimal blending stage that produced excellent quality yarn.

\section{Material and Methods}

The present study on the comparison of different blending techniques of bamboo and cotton at different stages during fibre to yarn spinning was carried out at the TIFAC-CORE, Kuamarguru College of Technology (KCT), Salem, Tamilnadu, India.

Cotton samples of Sankar-6 were taken from the mills, with average values of fibre properties as fibre length $27.27 \mathrm{~mm}$, fibre length uniformity ratio $49.58 \%$, fibre fineness $4.52 \mathrm{ug} / \mathrm{in}$, fibre maturity $82.53 \%$ and trash contents $0.19 \%$, while bamboo fibre having the quality characteristics as fibre length $36 \mathrm{~mm}$, moisture regain $11.42 \%$, elongation $21.2 \%$ was used in the study.

Table 1: Blend Ratio of Bamboo: Cotton

\begin{tabular}{|l|l|}
\hline S.No. & Blend ratio (bamboo: cotton) \\
\hline 1 & $100: 0$ (pure bamboo) \\
\hline 2 & $67: 33$ \\
\hline 3 & $50: 50$ \\
\hline 4 & $33: 67$ \\
\hline 5 & $0: 100$ (pure cotton) \\
\hline
\end{tabular}

The required percentage of blending was performed in the miniature blow room section. Then the lap of different blend ratios of bamboo and cotton (Table 1) were produced by the miniature blow room line. Then the produced laps were passed to the miniature carding machine to get the required sliver. After that the slivers were passed to the miniature drawing frame to get the more uniform and regular sliver. The sliver of $100 \%$ cotton and bamboo yarn was also produced in TIFAC-CORE of KCT. Then the required counts $\left(30^{\mathrm{s}}, 40^{\mathrm{s}}\right.$ and $\left.50^{\mathrm{s}}\right)$ of blended yarn of different blend ratios were produced in the Try Tex ring frame. Then the various properties of the blended yarn were tested in the testing department of Thiyagarajar polytechnic and Sona College of Technology, Salem, India. The entire tests like TPI tested by the twist tester, Strength is tested by the brand Tensile Strength Tester, yarn irregularities are tested by Uster Testing Machine and the hairiness of the yarn is determined by the Hairiness Tester. All the tests were performed in the standard condition of temperature and humidity.

\section{Results and Discussions}

In the table 2 and 3 all the properties of the blended yarn were nearer to each other. But the properties of 50:50/bamboo: cotton blended yarn were very nearer to $100 \%$ cotton yarn. On the other hand TPI and strength were also comparable to $100 \%$ cotton yarn although there was a variation among the tenacity. In the Table 4 and 5, it was seen that the variation of yarn properties were similar to the yarn properties of Table 2 and 3 . Here the strength and TPI of $50: 50$ blend was comparable to $100 \%$ cotton yarn. In the table 6 and 7 , it was observed that the variation of different properties among the blended yarns was comparable to the $100 \%$ cotton yarn. But the strength and tenacity of 67:33/bamboo:cotton blended yarn were very lower than that of the strength and tenacity of 50:50/bamboo:cotton blended yarn. The properties of 33:67/bamboo: cotton blended yarn were also nearer to the properties of 50:50/bamboo:cotton blended yarn. From the properties of each type of blended yarn it was observed that for 50:50 blend i.e., in case of balance blend all the properties were improved than that of other percentages of the blends. Hence all the properties were increasing with the increase of cotton in then blend and decreasing with increase of bamboo in the blend. It was also seen that the a Tenacity RKM values of individual of blended (50:50) yarn were very nearer to the Tenacity RKM values of $100 \%$ cotton count yarn. The main motive of blending was the cost minimization and to increase the utility of bamboo with cotton. The higher the percentage of bamboo with blend lesser will be the cost of the product. On the other hand, it should be kept in mind that the quality of the blended product has to be within the acceptable limit. Similar type of cotton yarn shows identical properties and for non blended products, there are also similarities to the properties of each individual. From the comparative results of 
50:50 blend it was seen that among the three types of yarn viz., $30^{\mathrm{s}}, 40^{\mathrm{s}}$ and $50^{\mathrm{s}}$ only $50^{\mathrm{s}}$ yarn showed acceptable properties which were nearer to the properties of $100 \%$ cotton yarn. So, the percentage of bamboo in the blended yarn had a strong effect on the properties of the various count of yarn.

Table 2: Relation between blend ratio and irregularities of $30^{\mathrm{s}}$ yarn

\begin{tabular}{|l|l|l|l|l|l|}
\hline $\begin{array}{l}\text { Sl. } \\
\text { No. }\end{array}$ & $\begin{array}{l}\text { Blend } \\
\text { ratio/Bambo } \\
\text { o: Cotton }\end{array}$ & Thick & Thin & $\begin{array}{l}\text { CV } \\
\%\end{array}$ & Hairiness \\
\hline 1 & $100: 0$ & 290 & 118 & 19 & 206 \\
\hline 2 & $67: 33$ & 282 & 96 & 18 & 192 \\
\hline 3 & $50: 50$ & 217 & 65 & 17 & 161 \\
\hline 4 & $33: 67$ & 257 & 58 & 16 & 182 \\
\hline 5 & $0: 100$ & 200 & 46 & 12 & 171 \\
\hline
\end{tabular}

Table 3: Relation between blend ratio and properties of $30^{\mathrm{s}}$ yarn

\begin{tabular}{|c|c|c|c|c|}
\hline S.No. & $\begin{array}{c}\text { Blend } \\
\text { ratio/Bam } \\
\text { boo: } \\
\text { Cotton }\end{array}$ & TPI & $\begin{array}{c}\text { Strengt } \\
\mathrm{h}\end{array}$ & $\begin{array}{c}\text { Tenacit } \\
\text { y RKM }\end{array}$ \\
\hline 1 & $100: 0$ & 19.27 & 206.4 & 5.67 \\
\hline 2 & $67: 33$ & 21.18 & 131.2 & 6.07 \\
\hline 3 & $50: 50$ & 22.11 & 187.0 & 8.77 \\
\hline 4 & $33: 67$ & 22.71 & 132.7 & 6.24 \\
\hline 5 & $0: 100$ & 23.14 & 201.1 & 9.47 \\
\hline
\end{tabular}

Table 4: Relation between blend ratio and irregularities of $40^{\mathrm{s}}$ yarn

\begin{tabular}{|c|c|c|c|c|c|}
\hline S.No. & $\begin{array}{c}\text { Blend } \\
\text { ratio/B } \\
\text { amboo: } \\
\text { Cotton }\end{array}$ & Thick & Thin & $\begin{array}{c}\text { CV } \\
\%\end{array}$ & $\begin{array}{c}\text { Hairin } \\
\text { ess }\end{array}$ \\
\hline 1 & $100: 0$ & 341 & 147 & 21 & 242 \\
\hline 2 & $67: 33$ & 333 & 125 & 20 & 211 \\
\hline 3 & $50: 50$ & 288 & 92 & 18 & 177 \\
\hline 4 & $33: 67$ & 294 & 84 & 17 & 163 \\
\hline 5 & $0: 100$ & 245 & 87 & 14 & 182 \\
\hline
\end{tabular}

Table 5: Relation between blend ratio and properties of $40^{\mathrm{s}}$ yarn

\begin{tabular}{|c|c|c|c|c|}
\hline S.No. & $\begin{array}{c}\text { Blend } \\
\text { ratio/B } \\
\text { amboo: } \\
\text { Cotton }\end{array}$ & TPI & $\begin{array}{c}\text { Stren } \\
\text { gth }\end{array}$ & $\begin{array}{c}\text { Tenacit } \\
\text { y RKM }\end{array}$ \\
\hline 1 & $100: 0$ & 21.77 & 246.3 & 6.68 \\
\hline 2 & $67: 33$ & 23.28 & 176.3 & 7.14 \\
\hline 3 & $50: 50$ & 28.04 & 182.2 & 9.54 \\
\hline 4 & $33: 67$ & 24.01 & 178.4 & 6.11 \\
\hline 5 & $0: 100$ & 24.53 & 214.2 & 10.17 \\
\hline
\end{tabular}

Table 6: Relation between blend ratio and irregularities of $50^{\mathrm{s}}$ yarn

\begin{tabular}{|c|c|c|c|c|c|}
\hline S.No. & $\begin{array}{c}\text { Blend } \\
\text { ratio/ } \\
\text { Bamboo: } \\
\text { Cotton }\end{array}$ & Thick & Thin & CV\% & Hairiness \\
\hline 1 & $100: 0$ & 362 & 169 & 22 & 241 \\
\hline 2 & $67: 33$ & 352 & 142 & 20 & 211 \\
\hline 3 & $50: 50$ & 303 & 111 & 17 & 178 \\
\hline 4 & $33: 67$ & 312 & 93 & 16 & 163 \\
\hline 5 & $0: 100$ & 286 & 90 & 13 & 184 \\
\hline
\end{tabular}

Table 7: Relation between blend ratio and properties of $50^{\mathrm{s}}$ yarn

\begin{tabular}{|c|c|c|c|c|}
\hline S.No. & $\begin{array}{c}\text { Blend } \\
\text { ratio/ } \\
\text { Bamboo: } \\
\text { Cotton }\end{array}$ & TPI & $\begin{array}{c}\text { Streng } \\
\text { th }\end{array}$ & $\begin{array}{c}\text { Tenacit } \\
\text { y RKM }\end{array}$ \\
\hline 1 & $100: 0$ & 22.77 & 255.4 & 7.01 \\
\hline 2 & $67: 33$ & 24.23 & 182.3 & 7.44 \\
\hline 3 & $50: 50$ & 28.38 & 187.1 & 9.99 \\
\hline 4 & $33: 67$ & 23.72 & 184.6 & 7.36 \\
\hline 5 & $0: 100$ & 25.05 & 226.1 & 10.27 \\
\hline
\end{tabular}




\section{Acknowledgement}

The authors express their sincere thanks to TIFAC-CORE in Textile Technology and Machinery of Kumaraguru College of Technology, Coimbatore India for permitting us to process all the samples in their advanced manufacturing laboratory.

\section{References}

[1] Duckett, K. E., Goswami, B. C., and Ramey, H. H., Jr., Mechanical Properties of Cotton/Polyester

Yarns, Textile Res. J., Vol. 49, 1979, pp .262-267 .

[2] Gupta, D. K., and Shiekl, A. E., The Mechanics of Blended Yams, Appl. Polym. Symp., Vol. 27, 1975, pp. 295-315.

[3] V. Svetnickienè and R. Čiukas, Investigation of friction properties of yarns from natural fibres, Mechanika, Vol. 1(75), 2009, pp. 73-76.

[4] Béchir Azzouz, Mohamed Ben Hassen and Faouzi Sakli, Adjustment of Cotton Fiber Length by the Statistical Normal Distribution: Application to Binary Blends, Journal of Engineered Fibers and Fabrics, Vol. 3(3), 2008, pp. 35-46.
[5] Pinar Duru Baykal, Osman Babaarslan Rizvan Erol, Prediction of Strength and Elongation Properties of Cotton/Polyester-Blended OE Rotor Yarns, Fibres \& Textiles in Eastern Europe, Vol. 14, 2006,pp. 1821.

[6] Pan, N., Chen, K., Monego, C. J., Backer,S., Studying the Mechanical Properties of Blended Fibrous Structures Using a Simple Model', Textile Research Journal, Vol. 70(6), 2000,pp. 502-507.

[7] Jianchun, Z., Peixing, F., 'Predicting the Tensile Strength of Lyocell/PET Blended Yarns', ITB International Textile Bulletin, Vol. 6(99), pp.28-30.

[8] Pan, N., Postle, R., Strengths of Twisted Blend Fibrous Structures: Theoretical Prediction of the Hybrid Effects, Journal of the Textile Institute, Vol. 86, 1995,pp. 559-580.

[9] Kemp, A., Owen, J. D., The Strength and Behaviour of Nylon/Cotton Blended Yarns Undergoing Strain', Journal of the Textile Institute, Vol. 46, 1995, pp. 684.

[10] Ratnam, T. V., Prediction of the Quality of Blended Yarns from that of the Individual Components, Textile Research Journal, Vol. 38, 1968, pp. 360365. 